\title{
EFFECT OF DIFFERENT DIETARY PROTEIN LEVELS WITH OR WITHOUT GUANIDINO ACETIC ACID ON SOME ILEAL MORPHOLOGY AND BLOOD BIOCHEMICAL PARAMETERS OF BROILER CHICKENS
}

\author{
A.S.M. Arafa ${ }^{1}$; A.I. El-Faham ${ }^{2}$; A.G. Abdallah ${ }^{1}$; M.H.S. El-Sanhoury ${ }^{2}$; Nematallah G.M. \\ Ali $^{2}$; M.A.M. Abddelaziz ${ }^{2}$ and A.Y.M. Abdelhady ${ }^{2}$ \\ ${ }^{1}$ Dept. Poult. Nut. Res. Anim., Prod. Res. Inst., Agric. Res. Center, Dokki, Giza, Egypt \\ ${ }^{2}$ Poultry Production Dept., Fac. of Agric., Ain Shams University, Cairo, Egypt
}

SUMMARY

\begin{abstract}
A 2 x 3 factorial study examined some ileal morphology and blood biochemical parameters of broiler chickens fed diets containing graded levels of crude protein with or without guanidino acetic acid (GAA). Six diets containing two levels of crude protein (standard levels $23.01,21.01,19.04 \%$ or low levels $21.00,19.03,17.07 \%$ ) in the starter, grower and finisher respectively supplemented with three levels $(0.0,0.06$ or $0.12 \%)$ of GAA were used. Each treatment was randomly assigned to 6 replicates (10 male Hubbard broiler chicks per replicates). The results indicated that: Some ileal morphology (Chicken fed standard diets have significantly $(\mathrm{P}<0.05)$ taller Villi height $(1269 \mu \mathrm{m})$ than those fed low protein $(-2 \% \mathrm{CP})$ diet $(1140$, $\mu \mathrm{m})$. In addition, significant differences were observed in Villi height values between chickens fed (0.0\% GAA) diets and those fed $(0.06$ and $0.12 \%$ GAA) diets $(1125,1271$ and $1217 \mathrm{~m})$ respectively, while, no significant differences were observed in villi width or crypt depth (m) among all treatments), and Some blood parameters (Dietary CP level (standard vs.-2 CP) and GAA supplementation level (0.0, 0.06 and $0.12 \%$ ) had a significant effect on all blood plasma parameters, examined herein, including levels of total protein, albumin, glubulin, $\mathrm{A} / \mathrm{G}$ ratio, total lipid, triglyceride and cholesterol. On the other hand, chicks fed low protein diets $(-2 \% \mathrm{CP})$ and (0.0\% GAA) have significantly higher values of total plasma lipid, cholesterol and triglycerides)
\end{abstract}

Keywords: broiler chickens, guanidino acetic acid, ileal morphology and blood biochemical parameters.

\section{INTRODUCTION}

Several experiments with broiler chicks have shown that performance is adversely affected with low crude protein diets and investigated the potential reasons for decreasing performance (Laudadio et al., 2012).

On the other hand, there is a lack of report linking the effects of dietary nutrients especially that of protein to the improve of the gastrointestinal tract of poultry. According to Yamauchi (2002), the morphological changes of the intestinal villi in chicks are dependent on the presence of digested nutrients in the small intestinal lumen.

A slower turnover rate of the intestinal epithelium results in a lower maintenance requirement, which can finally lead to a higher growth rate or growth efficiency of the animal (Van Nevel et al., 2005). Thus, the changes in intestinal morphology may influence nutrient metabolizability and performance. In addition, a deeper crypt may indicate faster tissue turnover to permit renewal of the villus, which suggests that the host's intestinal response mechanism is trying to compensate for normal sloughing or atrophy of villi due to inflammation from pathogens and their toxins (Gao et al., 2008).

A diet containing a standard protein level with an increase in villus height in the ileum and duodenum has been previously reported in broilers fed a diet with a low CP level ( $\geq 22 \%$, Sterling et al., 2005), and has been explained by the development of the intestinal villi, thus increasing the efficiency of digestion and absorption. Because long villi are correlated with improved gut health (Baurhoo et al., 2007),

Wykes et al. (1996) reported that a low protein diet reduced the rate of protein synthesis in most body tissues, particularly the intestine. Protein is known as the most important factor in recovery of the intestine 


\section{Arafa et al.}

after feed withdrawal (Maneewan and Yamauchi,2005). It also plays a critical role as a dietary constituent for development of morphological traits (Incharoen et al., 2010).

Maneewan and Yamauchi (2003) reported that semipurified protein free diets were the slowest in promoting histological recovery after feed withdrawal, suggesting that protein is the most important factor in recovery after feed withdrawal. Buwjoom et al. (2010), assessing the histology of intestinal villi and epithelial cells in broilers using long-term feeding of low-CP diets, found that the ileal villi did not show specific alterations and that the chronic feeding of a low-CP diet induced a histological alteration. Moreover, this report suggests that long villi, large cell area, and many cells undergoing mitosis might be observed even in hyponutritional conditions to obtain deficient nutrients, not just in the hypernutritional conditions. This suggests that the hypotrophied histological alterations can indicate that a diet is not nutritionally wellbalanced.

Moreover, Low et al., (2018) found that serum albumin (ALB) and total protein(TP) were linearly reduced by the dietary $\mathrm{CP}$ level reduction in both diets with and without protease $(\mathrm{p}<0.001, \mathrm{p}=0.042$, respectively) but was increasing for triglycerides (TG) and uric acid (UA). The level of TG increased linearly $(p<0.001)$ with the reduction of dietary CP in the protease supplemented group. Within the non-protease -supplemented group, the level of UA decreased quadratically $(\mathrm{p}<0.07)$.

Guanidino acetic acid is synthesized in the liver and kidney from Argnine and Glycine and subsequently methylated by S-adenosylmethionine to form creatine, (Dilger et al., 2013), and finally, ATP donates a phosphorus moiety to form the high-energy compound, phosphocreatine (Meister, 1965). Thus, GAA may be important for poultry nutrition not only as a replacement for dietary Arginine, an essential nutrient, but also to support overall energy homeostasis of the bird.

Tossenberger et al., (2016) studied the effect of GAA levels 0, 0.6, or $6.0 \mathrm{~g}$ GAA per kg of feed from 1 to 35 days of age. They indicated that supplementation of $0.6 \mathrm{~g} / \mathrm{kg}$ GAA did not improve weight gain (wg), although here a numerical improvement of about $0.07 \%$ units was observed. This is generally in contrast to other studies where addition of $0.6 \mathrm{~g} / \mathrm{kg} \mathrm{GAA}$ improved consistently BWG (Lemme et al., 2007a, 2007b, 2011; Michiels et al., 2012, Dilger et al.,2013), and breast meat yield (Lemme et al., 2007a, 2007b, 2010a; Heger et al., 2014) in broilers and turkeys.

Information on the effect of GAA supplement on intestinal morphology in poultry is limited. The vast majority of information has addressed the role of arginine on gut morphology and function. Murakami et al. (2014) reported benefits of arginine supplement on morphometry of the duodenum mucosa in broiler chickens.

Khajali et al. (2014) reported increased villus height, width, and absorptive surface area in the jejunum as a consequence of arginine supplementation $(10 \mathrm{~g} / \mathrm{kg})$. Increase in villus height increases total luminal villus absorptive area and subsequently results in satisfactory digestive enzyme action and higher transport of nutrients at the villus surface (Tufarelli et al., 2010).

Ahmadipour et al. (2018) found that the villus height, width and absorptive surface area in duodenum, jejunum, and ileum sections were significantly $(\mathrm{P}<0.05)$ improved at GAA supplementation above $0.5 \mathrm{~g} / \mathrm{kg}$. However, the crypt depth showed a significant decrease in all parts of the small intestine compared to the control.

Khakran et al. (2017) fed Hy-Line W-36 laying hens levels of GAA (0, 0.057, 0.114 and 0.171\%), and found that average blood biochemical parameters (Triglycerides, HD, LDL, AST and ALT) of chickens at 29 weeks of age did not differ among the treatments.

Therefore, this study was conducted to determine the best levels of GAA in standard or low protein diets to achieve their sparing effect on ileal morphology and blood biochemical parameters of broiler chickens.

\section{MATERIAL AND METHODS}

This study was carried out at poultry experimental and research station at Shalakan, Faculty of Agriculture, Ain Shams University, in order to evaluate the differences in histology of intestinal villi and blood biochemical parameters of broiler chickens fed on six starter, grower and finisher diets containing the studied two protein and three (GAA) levels. 


\section{Birds and management:}

Total of 360 one day old of male Hubbard broiler chicks were used, weighed and distributed into six experimental group (60 chick each) in $2 \times 3$ factorial completely randomized design (two protein and three GAA) levels. Each treatment group was consisted of six replicates of 10 chicks each. Chicks were reared in electrics heated batteries under similar hygienic, environmental and managerial conditions.

All chicks were vaccinated against the common viral diseases (NDV, IBDV) at the recommended periods. Feed and water were supplied ad-libitium and a constant (22 L: 2D) light period was provided during the experimental periods (1-35) day of age.

\section{Experimental diets:}

Six starter, grower and finisher diets were formulated to contain the studied protein and GAA levels. Three periodical diets were formulated in the experiments includes, starter (1-14), grower (15-28) and finisher (29-35) days of age. The standard diets (SD. $\mathrm{T}_{1}, \mathrm{~T}_{2}$ and $\mathrm{T}_{3}$ ) were formulated according to the manual guide of Hubbard broiler chicks, while tested diets (TD, T4, T5 and T6) were represent all requirements of birds except for crude protein which was reduced by about $2 \%$ of (starter grower or finisher) diets and each diets from (SD or TD) supplemented which $0.0,0.06$ or $0.12 \%$ GAA respectively. The dietary treatments were as follows:

$\mathrm{T}_{1}$ standard diets $(\mathrm{SD})+0.0 \%(\mathrm{GAA})$

$\mathrm{T}_{2}$ standard diets $(\mathrm{SD})+0.06 \%(\mathrm{GAA})$

$\mathrm{T}_{3}$ standard diets $(\mathrm{SD})+0.12 \%(\mathrm{GAA})$

$\mathrm{T}_{4}$ Tested diets $(-2 \% \mathrm{CP})+0.0 \%(\mathrm{GAA})$

$\mathrm{T}_{5}$ Tested diets $(-2 \% \mathrm{CP})+0.06 \%(\mathrm{GAA})$

$\mathrm{T}_{6}$ Tested diets $(-2 \% \mathrm{CP})+0.12 \%(\mathrm{GAA})$

- $\quad$ The standard and tested diets are shown in Table (1)

- GAA, CreAmino, contain 94\% guianido acetic acid and purchased from Evonik Industries

\section{Measurements}

\section{Blood sampling}

At the end of experimental period ( 35 days of age), five chickens were randomly taken from each dietary treatments and slaughtered. Blood samples were taken in dry clean centrifugation from the slaughtered birds and plasma were separated by centrifugation at $3000 \mathrm{rpm}$ for 15 minutes and assigned for subsequent determination.

Plasma samples were harvested after centrifugation of the clotted blood, stored at $-20^{\circ} \mathrm{C}$ in the deep freezer until time of chemical determinations.

\section{Some blood plasma components}

Biochemical analysis of blood plasma was conducted in Cairo University Research Park (CURP), Faculty of Agriculture. Quantitative determination of blood total protein, albumin, globulin, total lipids, cholesterol and triglycerides were calorimetrically determined using commercial diagnosing kits (Produced by Bio-diagnostic Company, Egypt).

\section{Some ileal morphological}

At the end of the experiment, representative tissue samples from ileum were taken to study the histological changes associated with the experimental treatments.

Three birds per treatment having the mean body weight of the group were used from each treatment for histological observations the tissue samples from the ileum of approximately midway between Meckel's diverticulum and the ileocaecal junction. Segments were flushed with saline solutions $(0.9 \% \mathrm{NaCl})$ to remove contents and were fixed in neutral buffered formalin solution for histology; samples were dehydrated, cleared The rotary type microtome was used for cutting the paraffin sections.

All sections were examined under electric microscope provided with computerized camera. Villus height, Villus width and crypt depth were determined and calculated. The values were measured with an oculometer 
at a magnification of $5 \mathrm{x}$ under a light microscope fitted with the stage micrometer and using an image analyzer (Leica Microsystems Co., Ltd, Germany) connected to a light microscope.

Table (1): Composition and calculated chemical analyses of experimental diets

\begin{tabular}{|c|c|c|c|c|c|c|}
\hline \multirow{2}{*}{ Ingredient $\%$} & \multicolumn{3}{|c|}{ Standard diet* } & \multicolumn{3}{|c|}{$-2 \%(\mathrm{CP})$ diet $* *$} \\
\hline & Starter & Grower & Finisher & Starter & Grower & Finisher \\
\hline Yellow corn & 51.55 & 57.23 & 62.59 & 56.91 & 62.61 & 67.92 \\
\hline Soybean meal (44\%) & 35 & 29.79 & 24.70 & 30.20 & 24.96 & 19.90 \\
\hline Corn gluten meal (62\%) & 5.20 & 4.90 & 4.60 & 4.70 & 4.40 & 4.10 \\
\hline Soy oil & 3.5 & 4.00 & 4.25 & 3.00 & 3.50 & 3.75 \\
\hline Limestone & 1.35 & 1.10 & 1.08 & 1.35 & 1.12 & 1.10 \\
\hline Di-calcium phosphate & 1.90 & 1.68 & 1.55 & 1.95 & 1.71 & 1.60 \\
\hline Premix $* * *$ & 0.30 & 0.30 & 0.30 & 0.30 & 0.30 & 0.30 \\
\hline Salt $(\mathrm{NaCl})$ & 0.40 & 0.40 & 0.40 & 0.40 & 0.40 & 0.40 \\
\hline Dl-Methionine & 0.31 & 0.24 & 0.21 & 0.37 & 0.30 & 0.26 \\
\hline Lysine $\mathrm{HCl}$ & 0.32 & 0.25 & 0.23 & 0.44 & 0.38 & 0.35 \\
\hline L-Arginine & 0.07 & 0.05 & 0.04 & 0.21 & 0.18 & 0.19 \\
\hline L-Threonine & 0.10 & 0.06 & 0.05 & 0.17 & 0.14 & 0.13 \\
\hline Total & 100 & 100 & 100 & 100 & 100 & 100 \\
\hline \multicolumn{7}{|l|}{ Calculated analysis $* * * *$} \\
\hline $\mathrm{ME}(\mathrm{kcal} / \mathrm{kg})$ & 3040 & 3151 & 3230 & 3045 & 3157 & 3235 \\
\hline $\mathrm{CP} \%$ & 23.01 & 21.01 & 19.04 & 21 & 19.03 & 17.07 \\
\hline Calorie / protein ratio $(\mathrm{C} / \mathrm{P})$ & 132 & 150 & 170 & 145 & 166 & 190 \\
\hline Calcium \% & 1.05 & 0.90 & 0.85 & 1.05 & 0.90 & 0.85 \\
\hline Available Phosphorous \% & 0.50 & 0.45 & 0.42 & 0.50 & 0.45 & 0.42 \\
\hline Methionine \% & 0.69 & 0.60 & 0.54 & 0.73 & 0.63 & 0.56 \\
\hline Methionine + cysteine $\%$ & 1.08 & 0.99 & 0.91 & 1.08 & 0.96 & 0.86 \\
\hline Lysine & 1.44 & 1.29 & 1.16 & 1.44 & 1.29 & 1.16 \\
\hline Arginine & 1.46 & 1.29 & 1.14 & 1.46 & 1.28 & 1.15 \\
\hline Threonine & 0.95 & 0.84 & 0.75 & 0.95 & 0.84 & 0.75 \\
\hline Tryptophan & 0.31 & 0.27 & 0.24 & 0.27 & 0.24 & 0.20 \\
\hline
\end{tabular}

* Standard diets: represent all requirements of birds according to standards requirement guide.

**-2\% (CP) diets: represent all requirements of birds according to requirements, except for crude protein which was reduced by about $2 \%$ of (starter, grower or finisher) diets.

*** Composition of each $3 \mathrm{~kg}$ of vitamin and minerals premix contain: 15000000 I.U VIT. A, 5000000IU Vit. D3, 50000 mg. VIT. E, $3000 \mathrm{mg}$. VIT. K3, $3000 \mathrm{mg}$. VIT. B1, $8000 \mathrm{mg}$. VIT. B2, $4000 \mathrm{mg}$. VIT. B6, $20 \mathrm{mg}$. VIT. B12, $15000 \mathrm{mg}$. Pantothenic acid, $60000 \mathrm{mg}$. Niacin, $1500 \mathrm{mg}$. Folic acid, $200 \mathrm{mg}$. Biotin, $200000 \mathrm{mg}$ VIT C, $700 \mathrm{gm}$. Choline chloride, $80 \mathrm{gm} . \mathrm{Mn}, 80 \mathrm{gm} . \mathrm{Zn}, 60 \mathrm{gm}$. Iron, $10 \mathrm{gm} . \mathrm{Cu}, 1 \mathrm{gm}$. Iodine, and $0.2 \mathrm{gm}$. Selenium, where CaCo3 was taken as a carrier up to $3 \mathrm{~kg}$, the inclusion rate was $3 \mathrm{~kg}$ premix / Ton feed

**** Calculated analyses of the experimental diets were done according to (NRC, 1994).

\section{Statistical analysis}

Data obtained were analyzed using the general linear models procedure of SAS software (SAS Institute, 2001). When differences among means were found, means were separated using Duncan's (Duncan's 1955) multiple ranges test at $(\mathrm{P}<0.05)$. The statistical model was:

$$
Y_{i j k}=\mu+D_{i}+E_{j}+D * E_{i j}+e_{i j k}
$$

Where: $Y_{\mathrm{ijk}} \quad=$ the effect of the observation, $\mu=$ The overall mean, $D_{i} \quad=$ The effect of the diets, $e_{j}$ $=$ The effect of the feed additives, $\mathrm{D} * \mathrm{E}_{\mathrm{ij}} \quad=$ The interaction between diets and feed additives, $\mathrm{e}_{\mathrm{ijk}}=$ The experimental error 


\section{RESULTS AND DISCUSSION}

\section{Effect of different dietary protein levels with or without guaindino acetic acid on some ileal morphology measurements of broiler chicks.}

Results of some ileal morphology values (Villi height and width, $\mu \mathrm{m})$ and crypt depth $(\mu \mathrm{m})$ are presented in Table (2) and Figure (1) and demonstrated that, chicken fed standard diets have significantly $(\mathrm{P}<0.05)$ longer Villi height $(1269, \mu \mathrm{m})$ than those fed low protein $(-2 \% \mathrm{CP})$ diet $(1140, \mu \mathrm{m})$. In addition, significant differences were observed in Villi height values between chickens fed $(0.0 \%$ GAA) diets and those fed $(0.06$ and $0.12 \%$ GAA) diets $(1125,1271$ and $1217 \mu \mathrm{m})$ respectively.

Table (2): Effect of different dietary treatments on some ileal morphology measurements, of broiler chickens

\begin{tabular}{|c|c|c|c|c|c|c|c|c|c|}
\hline \multirow{2}{*}{ Item } & \multirow{2}{*}{ Crude protein $(\mathrm{CP})$} & \multicolumn{3}{|c|}{$\mathrm{GAA} * \%$} & \multirow{2}{*}{ Overall } & \multicolumn{4}{|c|}{ Significant } \\
\hline & & 0.00 & 0.06 & 0.12 & & MSE & $\mathrm{CP}$ & GAA & $\mathrm{CP} * \mathrm{GAA}$ \\
\hline \multirow{3}{*}{ Villi height $(\mu \mathrm{m}) \#$} & Standard diets** & 1249 & 1324 & 1234 & $1269 a$ & & & & \\
\hline & $-2 \%(\mathrm{CP})$ diets $* * *$ & 1002 & 1219 & 1200 & $1140 \mathrm{~b}$ & 115 & $*$ & $*$ & $*$ \\
\hline & overall & $1125 b$ & $1271 \mathrm{a}$ & $1217 \mathrm{ab}$ & & & & & \\
\hline \multirow{3}{*}{ Villi width $(\mu \mathrm{m}) \# \#$} & Standard diets $* *$ & 229 & 332 & 261 & 274 & & & & \\
\hline & $-2 \%(\mathrm{CP})$ diets $* * *$ & 212 & 230 & 261 & 234 & 90 & NS & NS & NS \\
\hline & overall & 220 & 281 & 261 & & & & & \\
\hline \multirow{3}{*}{ Crypt depth $(\mu \mathrm{m})$} & Standard diets** & 142 & 135 & 187 & 155 & & & & \\
\hline & $-2 \%(\mathrm{CP})$ diets $* * *$ & 170 & 137 & 139 & 148 & 36 & NS & NS & NS \\
\hline & overall & 156 & 136 & 163 & & & & & \\
\hline
\end{tabular}

* GAA: Guanidino acetic acid.

** Standard diets: represent all requirements of birds according to standards requirement guide.

*** $-2 \%$ CP diets: represent all requirements of birds according to standards requirement guide, except for crude protein which was reduced by about $2 \%$ of (starter, grower or finisher) diets.

\# Tip to the bottom of villus

\#\#Width at villus base.

$a, b:$ Means in the same row or column with the same letters are not significantly different. MSE: Mean standard error NS: Non-significant, *: $(P \leq 0.05) * *:(P \leq 0.01)$

As shown in Figure (1) no significant differences were observed in villi width or crypt depth $(\mu \mathrm{m})$ between all treatments. Numerically, the chickens fed standard diets had the highest villi width $(274 \mu \mathrm{m})$ and crypt depth $(155 \mu \mathrm{m})$ compared with chickens that fed low protein diets, being (234 and $148 \mu \mathrm{m})$, respectively.

Also, villi width and crypt depth $(\mu \mathrm{m})$ for the chickens fed the diets containing all levels of GAA showed insignificant differences. However, the chickens fed diet containing (0.06\% GAA) had the highest villi width $(281 \mu \mathrm{m})$ and chickens fed $0.12 \%$ GAA had the highest crypt depth $(163 \mu \mathrm{m})$ compared with other dietary treatments.

Obtained results agree with those reported by Incharoen et al. (2012), Laudadio et al. (2012) and Low et al. (2018) who all reported that the dietary CP level influenced the morphology of the mucosa in the small intestine and the villus height in duodenum villus area decreased in the low CP group. In the same order Emami et al. (2016) and Ahmadipour et al. (2018) found that GAA supplementation to broiler diets villus surface area compared to control group.

Effect of different dietary protein levels with or without guanidine acetic acid on some blood parameters of chicks. 


\section{Arafa et al.}

Data of blood parameters for 5 weeks age broiler chicks fed the experimental diets containing different $\mathrm{CP}$ and/or supplemented with GAA are presented in Table (3) and Figures (2). It is evident that dietary CP level (standard vs.-2 CP) or GAA supplementation level (0.0, 0.06 and $0.12 \%$ ) had a significant effect on all blood plasma parameters, examined herein, including levels of total protein, albumin, glubulin, A/G ratio, total lipid, triglyceride and cholesterol.

Table (3): Effect of different dietary treatments on some blood plasma components of broiler chickens.

\begin{tabular}{|c|c|c|c|c|c|c|c|c|c|}
\hline \multirow[t]{2}{*}{ Item } & & \multirow{2}{*}{$\begin{array}{c}\begin{array}{c}\text { Crude } \\
\text { protein }(\mathrm{CP})\end{array} \\
0.00\end{array}$} & \multicolumn{2}{|c|}{$\mathrm{GAA} * \%$} & \multirow[t]{2}{*}{ overall } & \multicolumn{4}{|c|}{ Significant } \\
\hline & & & 0.06 & 0.12 & & MSE & $\mathrm{CP}$ & GAA & $\mathrm{CP}^{*} \mathrm{GAA}$ \\
\hline \multirow{3}{*}{$\begin{array}{l}\text { Total protein } \\
\qquad(\mathrm{g} / \mathrm{dl})\end{array}$} & $\begin{array}{l}\text { Standard } \\
\text { diets** }\end{array}$ & 2.50 & 3.84 & 3.53 & $3.29^{\mathrm{a}}$ & \multirow{3}{*}{0.12} & \multirow{3}{*}{$* *$} & \multirow{3}{*}{$* *$} & \multirow{3}{*}{$* *$} \\
\hline & $\begin{array}{l}-2 \%(\mathrm{CP}) \\
\operatorname{diets} * * *\end{array}$ & 2.31 & 3.47 & 2.81 & $2.86^{\mathrm{b}}$ & & & & \\
\hline & overall & $2.41^{\mathrm{c}}$ & $3.66^{\mathrm{a}}$ & $3.17^{\mathrm{b}}$ & & & & & \\
\hline \multirow{3}{*}{ Albumin (g/dl) } & $\begin{array}{l}\text { Standard } \\
\text { diets** }\end{array}$ & 1.15 & 1.25 & 1.30 & $1.23^{\mathrm{a}}$ & \multirow{3}{*}{0.07} & \multirow{3}{*}{$*$} & \multirow{3}{*}{$*$} & \multirow{3}{*}{$*$} \\
\hline & $\begin{array}{l}-2 \%(\mathrm{CP}) \\
\text { diets*** }\end{array}$ & 1.10 & 1.23 & 1.10 & $1.14^{\mathrm{b}}$ & & & & \\
\hline & overall & $1.13^{\mathrm{b}}$ & $1.24^{\mathrm{a}}$ & $1.2^{\mathrm{ab}}$ & & & & & \\
\hline \multirow{3}{*}{ Globulin (g/dl) } & $\begin{array}{l}\text { Standard } \\
\text { diets** }\end{array}$ & 1.35 & 2.59 & 2.23 & $2.06^{\mathrm{a}}$ & \multirow{3}{*}{0.08} & \multirow{3}{*}{$* *$} & \multirow{3}{*}{$* *$} & \multirow{3}{*}{$* *$} \\
\hline & $\begin{array}{l}-2 \%(\mathrm{CP}) \\
\text { diets**** }\end{array}$ & 1.21 & 2.24 & 1.71 & $1.72^{\mathrm{b}}$ & & & & \\
\hline & overall & $1.28^{\mathrm{c}}$ & $2.42^{\mathrm{a}}$ & $1.97^{\mathrm{b}}$ & & & & & \\
\hline \multirow{3}{*}{$\mathrm{A} / \mathrm{G}$ ratio } & $\begin{array}{l}\text { Standard } \\
\text { diets** }\end{array}$ & 0.85 & 0.48 & 0.58 & $0.64^{b}$ & \multirow{3}{*}{0.04} & \multirow{3}{*}{$* *$} & \multirow{3}{*}{$* *$} & \multirow{3}{*}{ NS } \\
\hline & $\begin{array}{l}-2 \%(\mathrm{CP}) \\
\text { diets*** }\end{array}$ & 0.91 & 0.55 & 0.65 & $0.70^{\mathrm{a}}$ & & & & \\
\hline & overall & $0.88^{\mathrm{a}}$ & $0.52 \mathrm{c}$ & $0.62^{\mathrm{b}}$ & & & & & \\
\hline \multirow{3}{*}{$\begin{array}{l}\text { Total lipid } \\
\text { (mg/dl) }\end{array}$} & $\begin{array}{l}\text { Standard } \\
\text { diets** }\end{array}$ & 1506.77 & 1142.24 & 1131.51 & $1260.17^{b}$ & \multirow{3}{*}{26.19} & \multirow{3}{*}{$* *$} & \multirow{3}{*}{$* *$} & \multirow{3}{*}{$* *$} \\
\hline & $\begin{array}{l}-2 \%(\mathrm{CP}) \\
\text { diets*** }\end{array}$ & 1908.98 & 1155.86 & 1412.75 & $1492.53^{\mathrm{a}}$ & & & & \\
\hline & overall & $1707.88^{\mathrm{a}}$ & $1149.05^{\mathrm{c}}$ & $1272.13^{\mathrm{b}}$ & & & & & \\
\hline \multirow{3}{*}{$\begin{array}{l}\text { Triglyceride } \\
\text { (mg/dl) }\end{array}$} & $\begin{array}{l}\text { Standard } \\
\text { diets** }\end{array}$ & 216.00 & 125.33 & 132.00 & $157.78^{b}$ & \multirow{3}{*}{15.85} & \multirow{3}{*}{$* *$} & & \\
\hline & $\begin{array}{l}-2 \%(\mathrm{CP}) \\
\text { diets*** }\end{array}$ & 267.33 & 144.67 & 146.00 & $186.00^{\mathrm{a}}$ & & & $* *$ & NS \\
\hline & overall & $241.67^{\mathrm{a}}$ & $135.00^{\mathrm{b}}$ & $139.00^{\mathrm{b}}$ & & & & & \\
\hline & $\begin{array}{l}\text { Standard } \\
\text { diets** }\end{array}$ & 154.49 & 110.27 & 112.49 & $125.75^{b}$ & & & & \\
\hline $\begin{array}{l}\text { Cholesterol } \\
(\mathrm{mg} / \mathrm{dl})\end{array}$ & $\begin{array}{l}-2 \%(\mathrm{CP}) \\
\text { diets*** }\end{array}$ & 166.88 & 113.67 & 126.64 & $135.73^{\mathrm{a}}$ & 5.08 & $* *$ & $* *$ & NS \\
\hline & overall & $160.69^{a}$ & $111.97^{\mathrm{c}}$ & $119.56^{\mathrm{b}}$ & & & & & \\
\hline
\end{tabular}

* GAA: Guanidino acetic acid.

** Standard diets: represent all requirements of birds according to standards requirement guide.

*** -2\% CP diets: represent all requirements of birds according to standards requirement guide, except for crude protein which was reduced by about $2 \%$ of (starter, grower or finisher) diets.

$a, b$ : Means in the same row or column with the same letters are not significantly different. MSE: Mean standard error NS: Non-significant, *: $(P \leq 0.05) * *:(P \leq 0.01)$

Significantly, best values were found in broiler chicks that fed, standard diets and diets supplemented with $0.06 \%$ GAA than other treatments. 
Dietary CP and GAA had significant effect on total protein $(\mathrm{P} \leq 0.05)$. The highest values was noticed when diet supplemented with $0.06 \%$ GAA than $0.12 \%$ and control. But standard diets had the highest value (3.2) than (-2\%) CP diet. These results also evident in albumin and globulin parameters. These results were logically, because decrease CP is effect on the protein metabolism and in birds body. Regarding to globulin and $\mathrm{A} / \mathrm{G}$ ratio, the results elucidated the GAA improve the bird's immunity especially $0.06 \%$ than $0.12 \%$ and control.

According to lipid metabolism the results illustrated that GAA supplementation had decreased total lipid, triglyceride and cholesterol concentration than control especially $0.06 \%$. That mean, these treatments had decreased the lipid metabolism and subsequently improved the bird's health. On the other hand, decreased $\mathrm{CP}$ in the diet had increased the triglyceride, and cholesterol concentrations in the body of the bird. These results normally logic, because any defect in the diet had reflected on the some substances metabolism in the bird's body.

On the other hand, chicks fed low protein diets $(-2 \% \mathrm{CP})$ and $(0.0 \%$ GAA) have significantly higher values of total plasma lipid, cholesterol and triglycerides, while, chicks fed standard diets and diets supplemented with GAA (0.06 and $0.12 \%)$ have significantly lowest values of these measurements of blood. Similarly, Kamran et al. (2004) studied the effect of lowering dietary crude protein (CP) with optimum limiting amino acids levels on blood parameters of broilers from 1 to 35 days of age and found that plasma uric acid concentration decreased and triglycerides concentration increased significantly by lowering the dietary CP content.

Gadelrab (2014) and Abd El-Hady (2012) who found no significant effects of protein programs (protein levels) and supplementing amino acid or with ME level on blood plasma constituents including levels of total protein, albumin, triglycerides, activities of transaminases (AST and ALT), total lipids and cholesterol.

\section{CONCLUSION}

From the present study, it could be concluded that supplemental low protein broiler diets $(-2 \% \mathrm{CP})$ with $0.06 \%$ (GAA) diet would have a positive effects on some ileal morphology and blood biochemical parameters. 


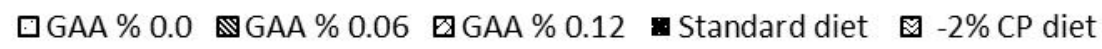

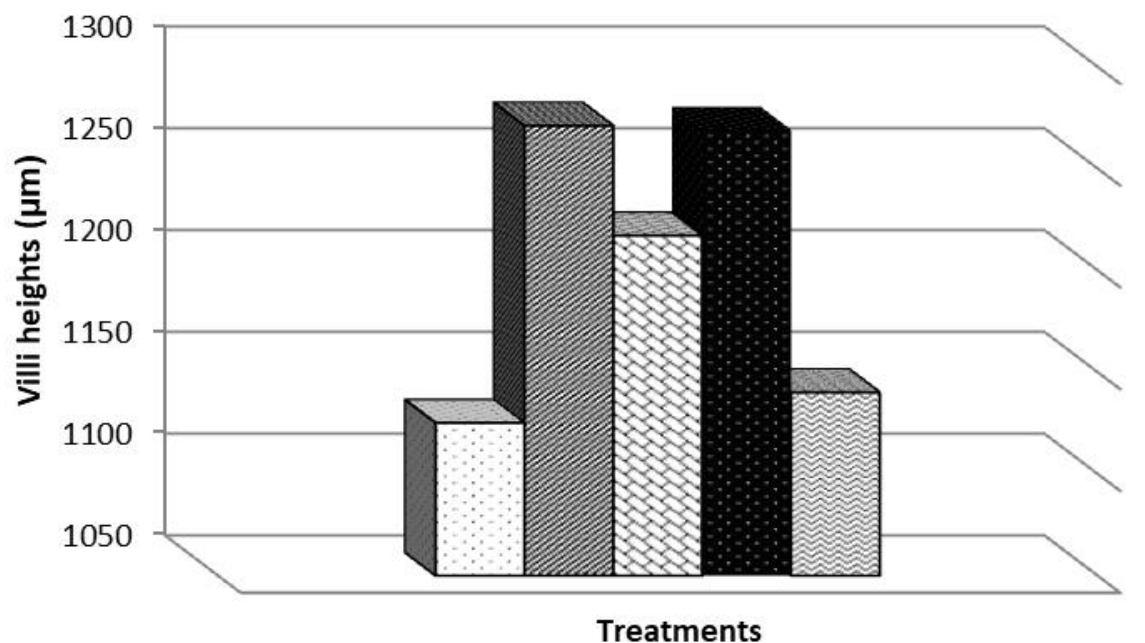

Fig. (1): Effect of different dietary treatments on some villi height of broiler chickens

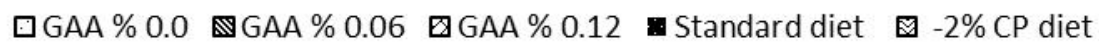

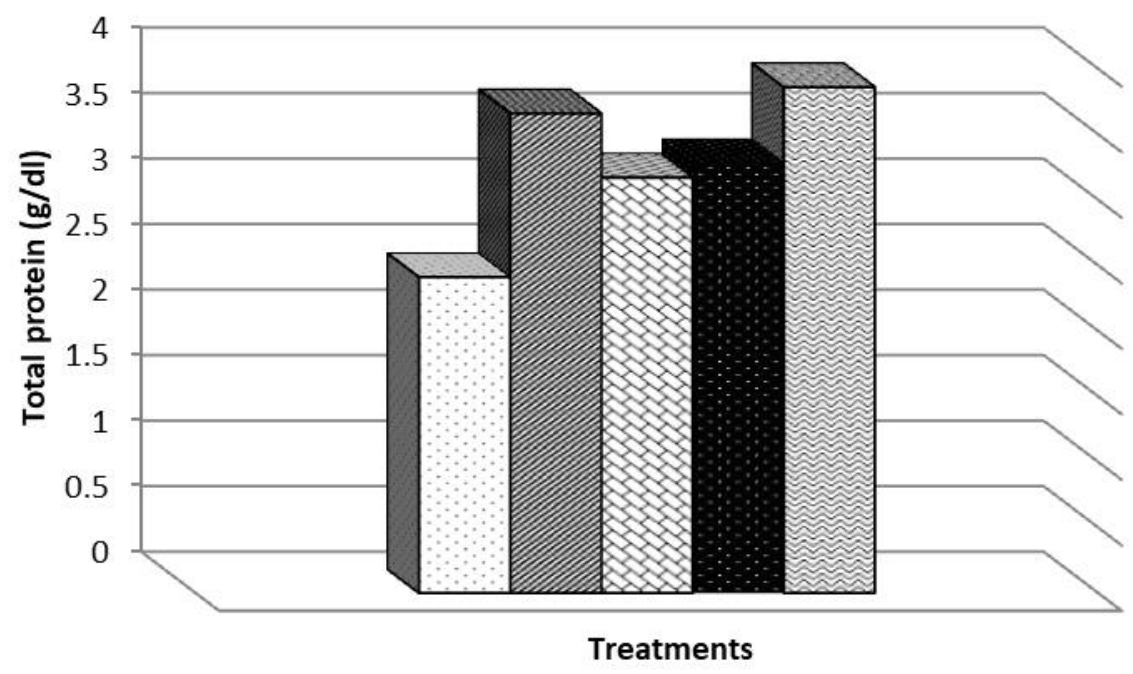




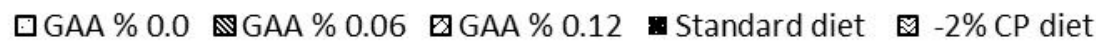

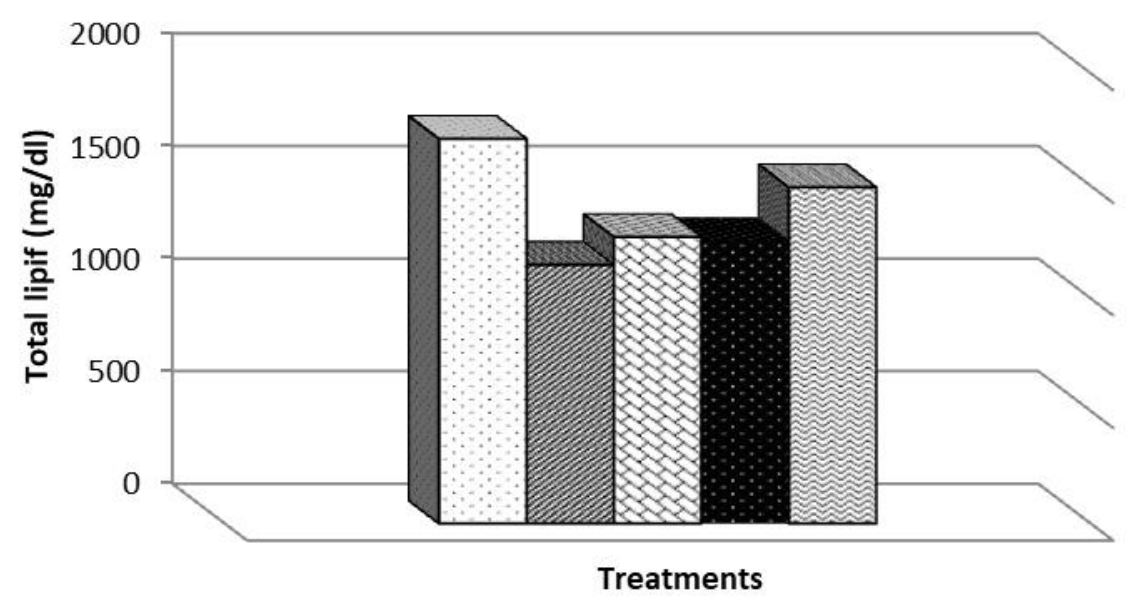

Fig. (2): Effect of different dietary treatments on some blood plasma components of broiler chickens

\section{REFERENCES}

Abd El-Hady, A.Y. (2012). Effect of enzyme preparation on apparent metabolizable energy of broiler diets. M.Sc. Thesis, Faculty of Agric., Ain Shams Univ., Egypt.

Ahmadipour B., F. Khajali and M. R. Sharifi (2018). Effect of guanidinoacetic acid supplementation on growth performance and gut morphology in broiler chickens. Poult. Sci. J. 2018, 6: 19-24.

Baurhoo, B., L. Phillip, and C.A. Ruiz-Feria. (2007). Effects of purified lignin and mannan oligosaccharides on intestinal integrity and microbial populations in the ceca and litter of broiler chickens. Poult. Sci., 86: 1070-1078.

Buwjoom T., K. Yamauchi, T. Erikawa, and H. Goto (2010). Histological intestinal alterations in chickens fed low-protein diet. J. Anim. Physiol. Anim. Nutr. (Berl.) 94:354-361.

diet energy. Poult. Sci., 75: 529-535.

Dilger R. N., K. Bryant-Angeloni, R. L. Payne, A. Lemme, and C. M. Parsons (2013). Dietary guanidino acetic acid is an efficacious replacement for arginine for young chicks. Poult. Sci., $92: 171-177$.

Duncan, D.B. (1955). Multiple ranges and multiple F test. Biometrics, 11: 1-42.

Emami N.K., A. Golian, D.D. Rhoads and M. Danesh Mesgaran (2016). Interactive effects of temperature and dietary supplementation of arginine or guanidinoacetic acid on nutritional and physiological responses in male broiler chickens. Br. Poult. Sci. 58: 1-8.

Gadlerab, S.S. (2014). Response of broiler chickens to varying amino acids feeding programs. Ph.D. Thesis, Faculty of Agric., Ain Shams Univ., Egypt.

Gao J., H. J. Zhang, S. H. Yu, S. G. Wu, I. Yoon, J. Quigley, Y. P. Gao, and G. H. Qi. (2008). Effects of yeast culture in broiler diets on performance and immunomodulatory functions. Poult. Sci., 87:13771384.

Heger, J., J. Zelenka, V. Machander, C. de la Cruz, M. Lestak, and D. Hampel (2014). Effects of guanidinoacetic acid supplementation to broiler diets with varying energy content. Acta Universitatis Agriculturae et Silviculturae Mendelianae Brunensis. 62:477-485. 


\section{Arafa et al.}

Incharoen T., K. Yamauchi, T. Erikawa, and H. Gotoh. (2010). Histology of intestinal villi and epithelial cells in chickens fed lowprotein or low-fat diets. Ital. J. Anim. Sci., 9:429-434.

Kamran, Z., M. Aslam Mirza, Ahsan-ul-Haq, and S. Mahmood. (2004). Effect of decreasing dietary protein levels with optimal amino acids profile on the performance of broilers. Pak. Vet. J. 24:161-164.

Khakran G., M. Chamani, F. Foroudi, A. A. Sadeghi and M. A. Afshar (2017). Effect of guanidine acetic acid addition to corn-soybean meal based diets on productive performance, blood biochemical parameters and reproductive hormones of laying hens. Kafkas Univ. Vet. Fak Derg 24: 99-105.

Laudadio V, L. Passantino and A. Perillo, G. Lopresti, A. Passantino, R. U. Khan, and V. Tufarelli (2012). Productive performance and histological features of intestinal mucosa of broiler chickens fed different dietary protein levels. Poult Sci., 91:265-70

Law F. L., I. Zulkifli, A. F. Soleimani, J. B. Liang, and E. A. Awad (2018). The effects of low-protein diets and protease supplementation on broiler chickens in a hot and humid tropical environment. Asian-Aust. J Anim Sci., 31:1291-1300.

Lemme A., J. Ringel, H., S. Rostagno and M. S. Redshaw (2007a). Supplemental guanidino acetic acid improved feed conversion, weight gain, and breast meat yield in male and female broilers. pp 1-4 in Proc. XVI Eur. Symp. on Poultry Nutr., Strasbourg, France.

Lemme A., J. Ringel, A. Sterk and J. F. Young (2007b). Supplemental guanidino acetic acid affects energy metabolism of broilers. pp 339-342 in Proc. XVI Eur. Symp. on Poult. Nutr., Strasbourg, France.

Lemme A., R. Gobbi, A. Helmbrecht, J. D. Van Der Klis, J. Firman, J. Jankowski, and K. Kozlowski. (2010a). Use of guanidino acetic acid in all-vegetable diets for turkeys. 4th Turkey Science and Production Conference, 57-61.

Lemme A., C. Elwert, R. Gobbi, and M. Rademacher. (2011). Application of the guanidino acetic acid as creatine source in broilers fed diets with or without fish meal. 18th Symposium on Poultry Nutrition, 453-455.

Maneewan B. and K. Yamauchi. (2003). Effects of semi-purified pellet diet on the chicken intestinal villus histology. Jpn. Poult. Sci., 40:254-266.

Maneewan B., and K. Yamauchi, K., (2005). Recovery of duodenal villi and cells in chickens refed protein, carbohydrate and fat. Br. Poult. Sci., 46: 415-423.

Meister A. (1965). Biochemistry of the amino acids. 2nd ed. Acad. Press, New York, NY.

Michiels J., L. Maertens, J. Buyse, A. Lemme, M. Rademacher, N. A. Dierick, and S. De Smet (2012). Supplementation of guanidinoacetic acid to broiler diets: Effects on performance, carcass characteristics, meat quality, and energy metabolism. Poult Sci $91: 402-412$.

NRC, (1994). Nutrient Requirements of Poultry. $9^{\text {th }}$ Revised edition. National Academy Press: Wasington, DC.

SAS (2001). SAS procedure guide version $6.12^{\text {th }}$ Ed. SAS Institute Inc., Cary, NC and UCA.

Sterling K. G., D. V. Vedenov, G. M. Pesti, and R. I. Bakalli. (2005). Economically optimal dietary crude protein and lysine levels for starting broiler chicks. Poult. Sci. 84:29-36.

Tossenberger J., M. Rademacher, K. N. emeth, V. Halas, and A. Lemme (2016). Digestibility and metabolism of dietary guanidino acetic acid fed to broilers. Poult. Sci. 95:2058-2067.

Van Nevel, C. J., J. A. Decuypere, N. A. Dieric, and K. Moll. (2005). Incorporation of galactomannans in the diet of newly weaned piglets: Effect on bacteriological and some morphological characteristics of the small intestine. Arch. Anim. Nutr. 59:123-138.

Wykes L. J., M. Fiorotto, D. G. Burrin, M. Del Rosario, M. E. Frazer, W. G. Pond and F. Jahoor (1996). Chronic low protein intake reduces tissue protein synthesis in a pig model of protein malnutrition. J. Nutr. 126:1481-1488.

Yamauchi K. (2002). Review on chicken intestinal villus histological alterations related with intestinal function. Jpn. Poult. Sci., 39:229-242. 
تأثير المستويات المختلفة من بروتين العليقة مع أو بدون إضافة جوانيدو أستيك أسيد على بعض الصفات

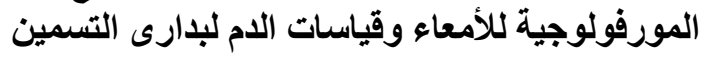

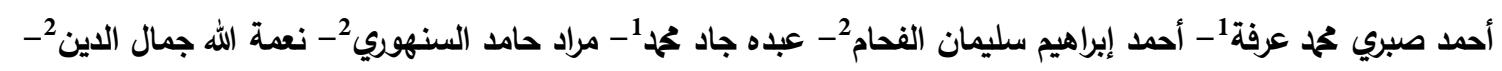

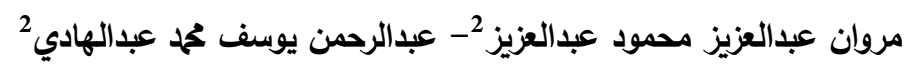

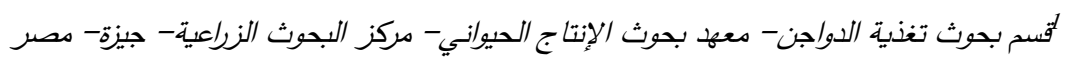

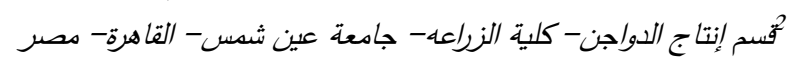

أجريت تجربة عاملية (2 × 3) لدراسة بعض الصفات المورفولوجية للأمعاء وقياسات الدم لبدارى التسمين المغذاة على علائق تحتوي

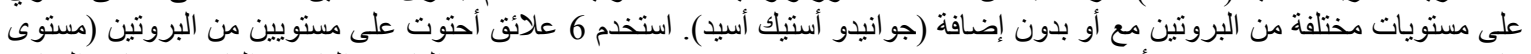

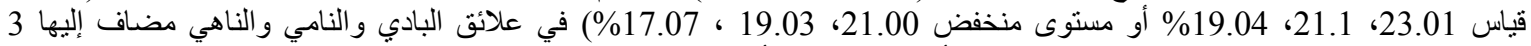
مستويات (0.0، 0.06، 0.12\%) من جو انيدو استيك أسيد. كل معاملة أحتوت على 6 مكررات بكل مكرر 10 كتاكيت ذكور هبرد عمر يوم.

$$
\text { * أهم النتائج المتحصل عليها: }
$$

ـ سجلت الطيور المغذاة على العلائق القياسية أعلى قيم لطول الخملات بالمقارنة بتلك المغذاة على عليقة منخفضة في البروتين (-262\%) 1269 مقارنة بـ 1140 ميكرون.

- سجلت الطيور المغذاة على عليقة بدون إضافة جو انيدو أستيك أسيد أقل القيم لطول الخملات بالمقارنة بتلك المضاف إليها بمعدل (0.06\%

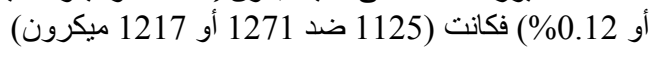

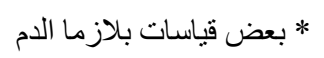

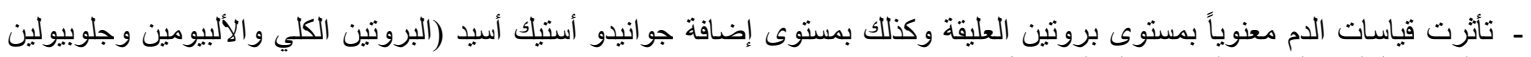
و الدهون الكلية والدهون الثلاثية و الكوليسترول).

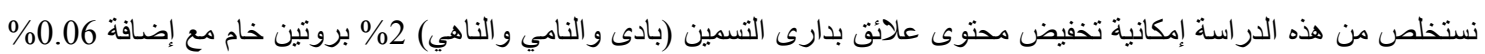

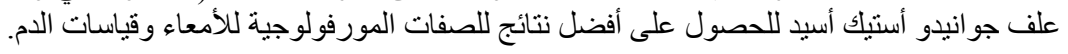

